\title{
MOVING TOWARD SUSTAINABLE IRRIGATION IN A SOUTHERN IDAHO IRRIGATION PROJECT
}

\author{
D. L. Bjorneberg, J. A. Ippolito, B. A. King, S. K. Nouwakpo, A. C. Koehn
}

Beyond 2020,

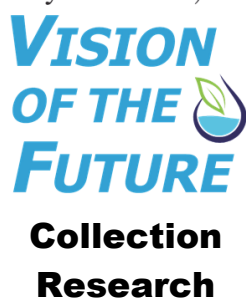

\section{Highlights}

- Private and public irrigation development was important for expanding agricultural production in the western U.S.

- The Twin Falls Canal Company is an excellent example of a successful Carey Act project.

- Cooperative efforts during the last 30 years have dramatically improved the water quality of irrigation return flow.

- Electricity generated by six hydroelectric facilities improves the sustainability of the irrigation project.

ABSTRACT. Private and public irrigation development projects were fundamental to bringing irrigation to arid regions of the western U.S. The Twin Falls Canal Company in southern Idaho provides a case study of private and public irrigation development because the project was developed by private investors under the Carey Act and receives a portion of its irrigation water supply from U.S. Bureau of Reclamation reservoirs. The project survived initial financial struggles and waterlogged soil to focus on sustaining crop production by reducing chronic furrow irrigation erosion and nutrient losses in irrigation return flow. Average sediment loss from the project was $460 \mathrm{~kg} \mathrm{ha}^{-1}$ in 1970. A cooperative effort by the canal company, state and federal agencies, and farmers improved water quality by installing sediment ponds on fields, applying polyacrylamide with furrow irrigation, converting from furrow to sprinkler irrigation, and constructing water quality ponds on irrigation return flow streams. From 2006 to 2018, more sediment and total phosphorus flowed into the watershed than returned to the Snake River, and the project removed 13,000 Mg of sediment and $30 \mathrm{Mg}$ of total phosphorus from the Snake

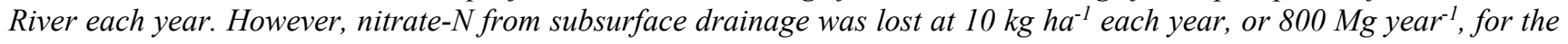
entire watershed. While sediment and phosphorus concentrations in irrigation return flow have decreased, these concentrations were still greater than the irrigation water, indicating that more can be done to reduce the project's influence on water quality in the Snake River.

Keywords. Nitrogen, Phosphorus, Sediment, Soluble salts, Water quality.

A $\mathrm{S}$ we look at the current state of irrigation in the U.S., it can be useful to consider how irrigation projects started. Private and public investments in irrigation projects played a key role in bringing irrigation to arid and semiarid areas in the western U.S. The Desert Lands Act of 1877 promoted reclamation of arid and semi-arid public lands by making land available for privately managed development (Ganoe, 1937). The Desert Lands Act

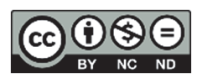

The authors have paid for open access for this article. This work is licensed under a Creative Commons AttributionNonCommercial-NoDerivatives 4.0 International License https://creative commons.org/licenses/by-nc-nd/4.0/

Submitted for review in February 2020 as manuscript number NRES 13955; approved for publication as a Research Article and as part of the National Irrigation Symposium 2020 Collection by the Natural Resources \& Environmental Systems Community of ASABE in May 2020.

Mention of company or trade names is for description only and does not imply endorsement by the USDA. The USDA is an equal opportunity provider and employer.

The authors are David L. Bjorneberg, Supervisory Research Agricultural Engineer, USDA-ARS Northwest Irrigation and Soils Research Laboratory, Kimberly, Idaho; James A. Ippolito, Associate Professor, Department of Soil and Crop Sciences, Colorado State University, Fort Collins, Colorado; Bradley A. King, Research Agricultural Engineer, S. Kossi Nouwakpo, Research Soil Scientist, and Anita C. Koehn, Soil Scientist, USDA-ARS Northwest Irrigation and Soils Research Laboratory, Kimberly, Idaho. Corresponding author: David Bjorneberg, 3793 N 3600 E, Kimberly, ID 83341; phone: 208-423-6521; email: dave.bjorneberg@usda.gov. originally allowed individuals to claim up to 260 ha (640 acres) if they improved the property by bringing irrigation water to the land and growing crops. The Desert Lands Act resulted in a rapid increase of irrigated land from 620,000 ha in 1869 to 3.3 million ha by 1889 (table 1). Within a short time after passage of the Desert Lands Act, there were assertions that many of the irrigation claims were fraudulent and that the law was primarily being used to gain control of water rather than developing agricultural land (Ganoe, 1937). Thus, the Desert Lands Act was amended in 1891 to require each person claiming land to show "how he intended to irrigate the land, provided for the filing of joint or association irrigation plans, required minimum annual and total reclamation expenditures, limited entries to individual citizens, and extended the operation of the act to Colorado" (Landstrom, 1954).

Individuals could bring water to sites adjacent to streams that did not require major infrastructure development, but larger development required more resources. Corporations and private businesses conducted reclamation projects under the Carey Act of 1894, which allowed them to profit from the sale of water to settlers on the reclaimed land (Lovin, 1987). The Carey Act was particularly successful in Idaho, which according to the 1920 U.S. Census had $13 \%$ of the irrigated land in the U.S. but $73 \%$ of the land developed un- 
Table 1. Irrigation area (ha) by irrigation enterprise from the 1920 U.S. Census (Census, 1922).

\begin{tabular}{cccccccc}
\hline & $\begin{array}{c}\text { Individual and } \\
\text { Year }\end{array}$ & Partnership & Cooperative & $\begin{array}{c}\text { Irrigation } \\
\text { District }\end{array}$ & Commercial & $\begin{array}{c}\text { U.S. Reclamation } \\
\text { Service }\end{array}$ & $\begin{array}{c}\text { Carey } \\
\text { Act }\end{array}$ \\
\hline 1860 & 25,750 & 71,505 & 810 & 5,618 & - & - & 103,683 \\
1869 & 179,435 & 392,733 & 38,734 & 9,479 & - & - & 620,380 \\
1879 & 493,222 & 733,886 & 134,008 & 303,610 & - & - & $1,664,726$ \\
1889 & $1,131,039$ & $1,440,665$ & 294,154 & 414,172 & - & $3,280,031$ \\
1899 & $1,497,344$ & $1,749,385$ & 455,113 & 527,459 & - & 20,589 & $4,249,890$ \\
1904 & $1,734,982$ & $2,066,782$ & 480,323 & 599,649 & 149,371 & 119,198 & $5,150,306$ \\
1909 & $1,911,787$ & $2,321,349$ & 583,201 & 667,860 & 457,614 & 208,776 & $6,150,588$ \\
1914 & $2,215,355$ & $2,475,286$ & 650,638 & 713,630 & 499,055 & 211,247 & $6,765,211$ \\
1919 & $2,512,919$ & $2,543,797$ & 733,587 & 721,044 & 502,150 & 211,267 & $7,224,764$ \\
\hline
\end{tabular}

der the Carey Act (Census, 1922). Projects initially developed under the Carey Act usually transferred to cooperative enterprises after the project was developed, so the full impact of the act is not shown in table 1 . When the Reclamation Act was passed in 1902, many sites that were easier or less costly to develop were already claimed. This act created the Reclamation Service and paved the way for federal funding to develop irrigation projects. Settlers developed farm land and repaid the federal government for the cost of bringing water to their farms. In 1909, irrigation water was supplied to $46 \%$ of the irrigated land by individual and partnership enterprises, $32 \%$ by cooperative enterprises, $4 \%$ by irrigation districts, and $3 \%$ by the U.S. Bureau of Reclamation (table 1). By 1919 , these percentages changed to $36 \%$ for individual and partnerships, $34 \%$ for cooperatives, $9 \%$ for irrigation districts, and 7\% for the U.S. Bureau of Reclamation. Similar to the Carey Act, the data do not fully represent the contribution of the U.S. Bureau of Reclamation because it often supplies water from reservoirs to irrigated land that is primarily served by other enterprises (Census, 1922). Irrigation organizations supplied irrigation water to $50 \%$ to $75 \%$ of the irrigated land until 1969, after which increases in irrigated area were primarily from groundwater sources (fig. 1). The increase in groundwater irrigation corresponded with an increase in sprinkler irrigation (fig. 2).

Managing irrigation is more complex when water is supplied by off-farm sources, especially on larger projects that distribute water through a system of canals. The farmer does not control the irrigation source and usually needs to schedule water delivery one to three days in advance for a specific duration, flow rate, volume, or some combination. Once scheduled, irrigation delivery may not be flexible to allow for changing conditions (e.g., rainfall, delayed field operations), and the farmer may be required to accept water delivery or the unused water is discharged from the project. The off-farm supplier may divert additional water to ensure that an adequate supply is available throughout project.

The Twin Falls Canal Company (TFCC) in southern Idaho provides a classic case of irrigation development in the western U.S. The objective of this study is to provide a brief overview of the TFCC history to show how this project progressed from the early challenges of reliable irrigation water delivery to the current challenges of minimizing impacts on water quality in the Snake River. Since 2005, water flowing into the TFCC project and returning to the Snake River has been monitored as part of the USDA Conservation Effects Assessment Project (CEAP) on the Upper Snake-Rock watershed. Water quality data from 2006 to 2018 are presented to show current trends for water quality parameters and impacts of irrigation conservation practices.

\section{Materials ANd Methods IRRIGATION STATISTICS}

The data shown in figures 1 and 2 were obtained from various census reports. Irrigated area in the U.S. by irrigation

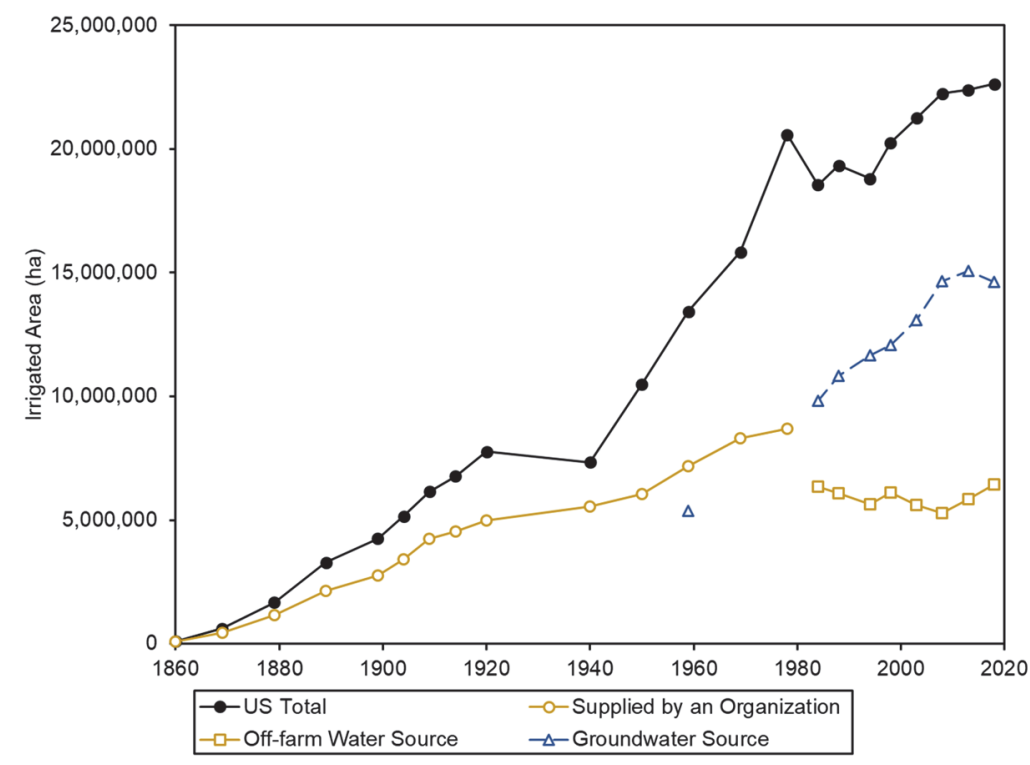

Figure 1. U.S. irrigated area by water source. Data obtained from U.S. Census and USDA Census of Agriculture (USDA, 2020a, 2020b). 


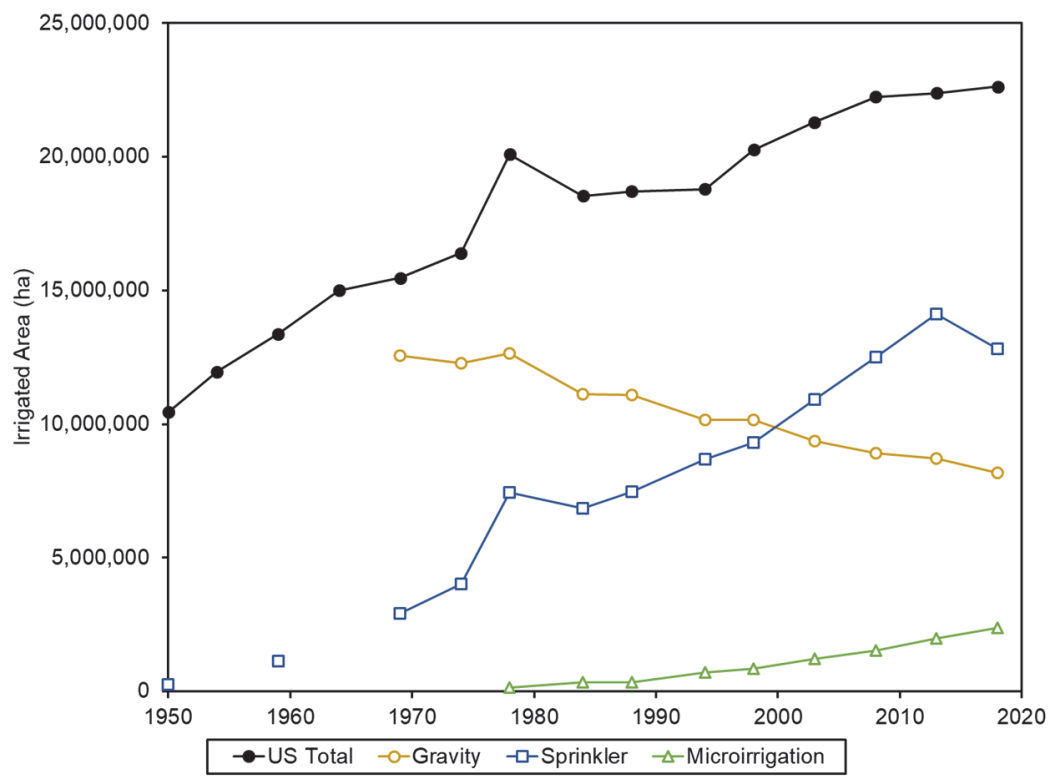

Figure 2. U.S. irrigated area by application method. Data obtained from U.S. Census and USDA Census of Agriculture (USDA, 2020a, 2020b).

type or water source for 2007 to 2018 were obtained from the Census of Agriculture (USDA, 2020b). Irrigation statistics prior to 2007 were obtained from Census of Agriculture reports and U.S. Census reports that are in the USDA Census of Agriculture Historical Archive, which is a collaborative project between the Albert R. Mann Library at Cornell University and the USDA National Agricultural Statistics Service (USDA, 2020a).

\section{TFCC HISTORY}

The Twin Falls south side project was developed under the Carey Act by the Twin Falls Land and Water Company. The company sold water rights to settlers for $\$ 62 \mathrm{ha}^{-1}$ (\$25 per acre) on 10-year payment at $6 \%$ interest (Carey Act, 1912). The approximate development cost was $\$ 4,000,000$. Technology changes resulted in unforeseen costs, such as the need to install telephone lines to settlers' homes and bridges over smaller canals as telephones and automobiles became popular (Carey Act, 1912). People were reluctant to invest in developing the farmland unless they had telephone service at their home and access by automobile.

The Twin Falls south side project began delivering irrigation water in 1905. This irrigation project is located on the south side of the Snake River and is bounded by 100 to 150 $m$ deep canyons on the north (Snake River) and west (Salmon Falls Creek) and irrigation canals on the east and south (fig. 3). The TFCC has been operating the system, consisting of $180 \mathrm{~km}$ of main canals and over $1,600 \mathrm{~km}$ of laterals, since 1909 (Moon and Tremayne, 2005). The primary water right for TFCC is a $85 \mathrm{~m}^{3} \mathrm{~s}^{-1}\left(3000 \mathrm{ft}^{3} \mathrm{~s}^{-1}\right)$ natural flow water right for the Snake River with a 1900 priority date (TFCC, 2020). The project was designed to equally distribute this natural flow water right to 97,000 ha (240,000 acres) so each farm would receive $50 \mathrm{~L} \mathrm{~min}^{-1} \mathrm{ha}^{-1}\left(1 / 80 \mathrm{ft}^{3} \mathrm{~s}^{-1}\right.$ per acre) during the entire irrigation season as long as water was available. The TFCC later acquired another $22 \mathrm{~m}^{3} \mathrm{~s}^{-1}$ of natural flow rights and 47,500 ha-mm of water in U.S. Bureau of Reclamation reservoirs. While the final developed project

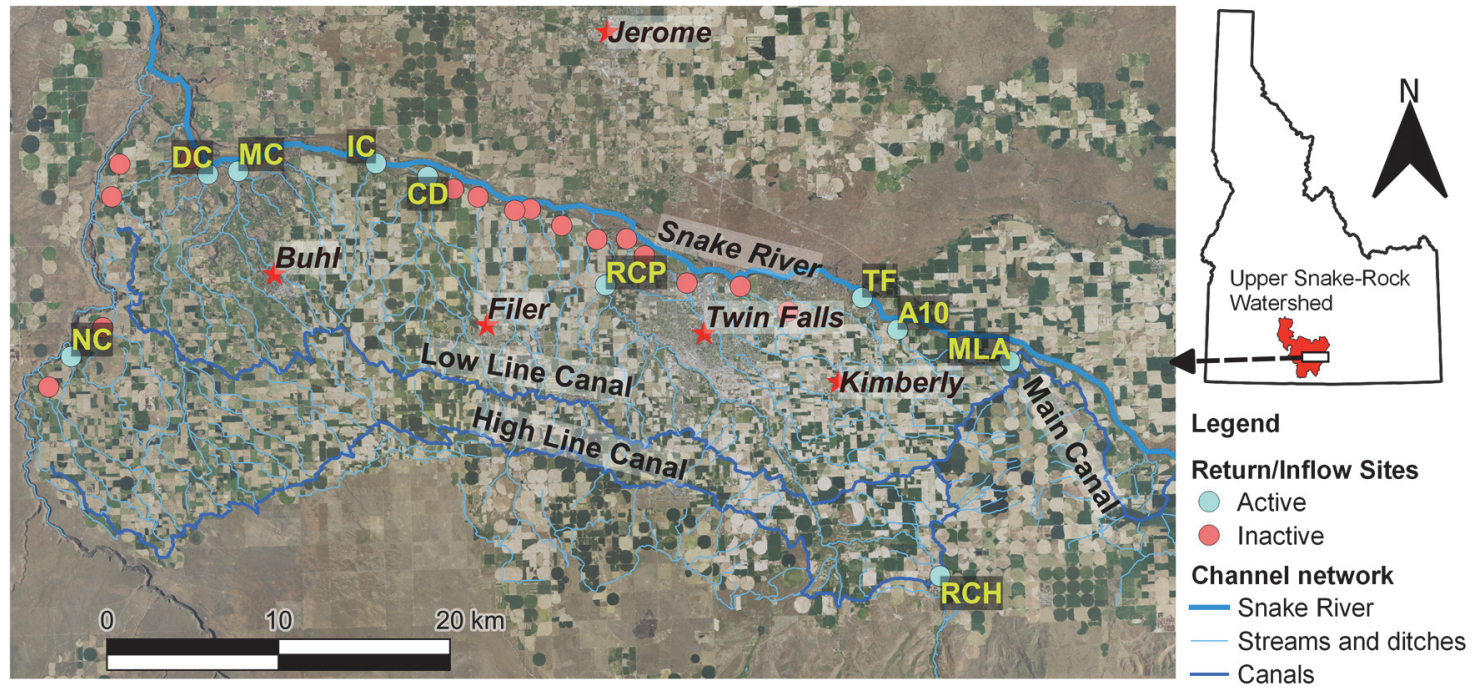

Figure 3. Map of Twin Falls irrigation project. Active sites were monitored from 2006 to 2018; inactive sites were monitored from 2006 to 2008. 
area was 82,000 ha, TFCC continues to use the flow rate water allocation to provide irrigation water to farms.

By 1920, seepage from canals, laterals, irrigation ditches, and fields raised the water table in some areas of the TFCC, saturating the soil and making some fields waterlogged and useless (Carter et al., 1971). Developers originally thought that seepage and deep percolation would flow out of the canyon walls, like the springs on the north side of the Snake River, but it did not. To solve the drainage problem, $1.2 \mathrm{~m}$ wide by $1.8 \mathrm{~m}$ high tunnels were dug into the basalt in areas that had become saturated, essentially constructing artificial springs. Approximately 50 tunnels ranging from 400 to 2,400 $\mathrm{m}$ long were constructed (Carter et al., 1971). The last tunnel was completed in 1948 at a cost of $\$ 8.40 \mathrm{~m}^{-1}$ (Moon and Tremayne, 2005). An alternative to drain tunnels was relief wells that were drilled 10 to $20 \mathrm{~m}$ deep and connected by drain tiles that removed the water. Water flows by hydrostatic pressure up through the relief wells to the drain tile. Water flows from the drain tunnels and tiles to natural channels or coulees that also carry irrigation return flow to the Snake River.

\section{Crop ANd Livestock Production}

All crops grown in the Twin Falls irrigation project are irrigated because annual precipitation is only $260 \mathrm{~mm}$ and average monthly precipitation from June through September is $<15 \mathrm{~mm}$ (Bjorneberg et al., 2020). The main crops are alfalfa, corn, dry bean, barley, wheat, sugar beet, and potato. These crops are grown under a variety of crop rotations, and the amount of each crop planted each year was consistent from 2006 to 2018 (Bjorneberg et al., 2020). The number of dairy cows in Twin Falls County increased rapidly from 13,000 in 1990 to 69,000 in 2008 and has stabilized at about 65,000 (USDA, 2020b). Not all of these dairies are within the Twin Falls irrigation project, but the growth in dairy production resulted in more corn grown for grain and ensilage within the watershed. Corn production in Twin Falls County increased linearly from 4000 ha in 1995 to 20,000 ha in 2007 and continued to increase at a slower rate to 24,000 ha in 2017 (USDA, 2020b).

\section{WATER QUALITY MONITORING}

Water quality monitoring on the Twin Falls irrigation project has been conducted during three time periods. Irrigation return flow was first monitored from 1968 to 1971 by Carter et al. (1971, 1974). Water quality monitoring for CEAP was conducted during 2006 to 2008 and 2012 to 2018 . A total of 24 return flow and two inflow sites were sampled weekly during 2006 to 2008 (fig. 3). The 24 return flow sites constitute all of the main streams and ditches that convey water back to the Snake River. The two inflow sites, the main irrigation canal (MLA) and Rock Creek (RCH), were the only two sources of water flowing into the watershed. Site, sampling, and analysis procedures were described in more detail by Bjorneberg et al. (2015). Monitoring sites were reduced in 2012 to seven main return flow streams and the two inflow sites due to resource limitations (fig. 3). Site TF (fig. 3) was started again in 2015 when TFCC began planning a water quality project on that return flow stream. One $2 \mathrm{~L}$ grab sample was collected at each site weekly dur- ing the irrigation season (April to October) and biweekly during the winter. Water stage was measured continuously with pressure transducers connected to data loggers at all seven sites in cooperation with the Idaho Department of Water Resources (IDWR). Flow rate was calculated from stagedischarge relationships that were defined at each site by IDWR.

From 2006 to 2008, all water samples were refrigerated until processed within $24 \mathrm{~h}$ of collection (Bjorneberg et al., 2008). After 2012, samples were processed on the day they were collected. During sample processing, samples were stirred for 1 to $2 \mathrm{~min}$ on a stir plate before measuring $\mathrm{pH}$ and electrical conductivity and collecting an unfiltered $50 \mathrm{~mL}$ aliquot and a $15 \mathrm{~mL}$ filtered aliquot $(0.45 \mathrm{~mm})$ that was stabilized with $0.2 \mathrm{~mL}$ of saturated boric acid. A third aliquot was used to determine sediment concentration by filtering a known volume $(\sim 100 \mathrm{~mL})$ through $0.45 \mathrm{~mm}$ filter paper and weighing the dried filter paper $\left(60^{\circ} \mathrm{C}\right.$ for $\left.24 \mathrm{~h}\right)$ before and after sediment collection. Filtered water samples were analyzed by inductively coupled plasma optical emission spectroscopy (ICP-OES, PerkinElmer) to determine phosphorus (P), calcium, magnesium, and sodium concentrations and by flow injection analysis to determine nitrate- $\mathrm{N}$, ammonium$\mathrm{N}$, and chloride concentrations at the USDA-ARS laboratory in Kimberly, Idaho. An aliquot $(\sim 25 \mathrm{~mL})$ of the unfiltered water sample was digested with a Kjeldahl procedure (USEPA, 1983) and analyzed by ICP-OES for total P and by flow injection analysis for ammonium-N. Electrical conductivity $\left(\mu \mathrm{S} \mathrm{cm}^{-1}\right)$ was multiplied by 0.64 to convert to $\mathrm{mg} \mathrm{L}^{-1}$ of soluble salt (Cuenca, 1989).

The flow volume at each site was calculated for each sampling interval. This volume was multiplied by the parameter concentrations from the laboratory analysis to calculate mass loads. Loads were summed over appropriate intervals (e.g., yearly or monthly) to determine total input or output of a parameter. Flow-weighted concentrations were calculated by dividing the mass load for a time period by the total flow volume for the same period. Annual totals were based on the calendar year.

Only the seven sites that were monitored continuously during 2006 to 2008 and 2012 to 2018 were included when analyzing trends over time. These seven sites contributed $70 \%$ to $80 \%$ of the total return flow from 2006 to 2008 . The 24 return flow sites that were monitored during 2006 to 2008 captured essentially all the irrigation return flow. These data were used to calculate total return flow loads for each parameter for that time period. To estimate total return flow loads for 2012 to 2018, the relative amount of return flow from the seven sites during 2006 to 2008 was calculated for each month. Total monthly return flow loads for 2012 to 2018 were then estimated by dividing the loads measured at the seven sites during 2012 to 2018 by the relative monthly contributions for these seven sites during 2006 to 2008. This method for estimating total loads for 2012 to 2018 assumed that any changes in flow or parameter concentrations that occurred during this time period were proportional among all return flow streams.

Mann-Kendall trend analysis was used to determine if there was a $95 \%$ probability that parameters were increasing or decreasing during the 2006 to 2018 measurement period 
(SAS, 2014). Paired t-tests were used to determine difference between total annual inflow and return flow concentrations and loads.

\section{RESULTS AND DISCUSSION}

The hydrology of the TFCC watershed is highly managed due to the delivery of irrigation water to fields and the irrigation return flow from furrow irrigation runoff, unused irrigation water, and drain tunnel/tile flow. During the irrigation season (April to October), stream channels receive unused irrigation water and furrow irrigation runoff from fields. This water is diverted where possible to irrigation laterals that deliver irrigation water to other fields. Many stream channels only have water flowing during the irrigation season. The only streams that flow continuously receive water from drain tunnels/tiles. Annual precipitation is only $260 \mathrm{~mm}$ and seldom causes runoff (Bjorneberg et al., 2020), while the main irrigation canal supplies more than $1200 \mathrm{~mm}$ to the watershed during the irrigation season. The only water flowing into the watershed is irrigation water in the main canal and Rock Creek, which is an ephemeral stream that supplied less than $2 \%$ of the total inflow to the watershed (Bjorneberg et al., 2020).

Improving water quality has been a focus for the last 30 years. Farmers have generally improved furrow irrigation management. They apply polyacrylamide to reduce furrow irrigation erosion (Lentz et al., 1992), install sediment basins to capture sediment before water leaves their fields, and convert from furrow irrigation to sprinkler irrigation. Approximately $90 \%$ of the cropland in the TFCC watershed was furrow irrigated in 1970 (Carter et al., 1974). Farmers began converting furrow irrigated land to sprinkler irrigation in the 1990 s with financial assistance from USDA programs. Almost $60 \%$ of the cropland was sprinkler irrigated in 2016 (Bjorneberg et al., 2020). TFCC has also participated in cooperative projects to construct more than 20 water quality ponds to capture sediment and phosphorus from irrigation return flow.

\section{SEDIMENT}

TFCC cropland is predominately silt loam with low organic matter and high erodibility. Precipitation rarely causes runoff and soil erosion in this watershed. Approximately $70 \%$ of the precipitation from 2006 to 2016 occurred during events that were $<10 \mathrm{~mm}$ (Bjorneberg et al., 2020). Water flowing in furrows can cause substantial erosion, transporting sediment and nutrients to return flow streams. In 1971, the main irrigation canal supplied $920 \mathrm{~kg} \mathrm{ha}^{-1}$ of sediment to the TFCC watershed, while $1380 \mathrm{~kg} \mathrm{ha}^{-1}$ flowed back to the Snake River with return flow (Carter et al., 1974). This resulted in an annual net sediment loss of 460 $\mathrm{kg} \mathrm{ha}^{-1}$ from this watershed, with a flow-weighted sediment concentration of $304 \mathrm{mg} \mathrm{L}^{-1}$ in the return flow (Carter et al., 1974). Brown et al. (1974) measured sediment concentrations $>1000 \mathrm{mg} \mathrm{L}^{-1}$ in three TFCC return flow streams in 1971 (one sample was 14,500 $\mathrm{mg} \mathrm{L}^{-1}$ ), which were caused by excessive sediment loss from furrow irrigated fields. Berg and Carter (1980) documented annual sediment losses of 500 to $141,000 \mathrm{~kg} \mathrm{ha}^{-1}$ on 49 fields within the TFCC during 1978 and 1979. A smaller study of six fields in 2003 indicated that losses from individual fields have decreased, but annual sediment losses still ranged from 2000 to 33,000 $\mathrm{kg} \mathrm{ha}^{-1}$ (Bjorneberg et al., 2007).

Data collected since 2006 showed that more sediment flowed into the watershed each year than flowed back to the Snake River (fig. 4). Note that the total return flow loads during 2012 to 2018 were estimated based on data from the seven sites that were monitored during that time period. Annual inflow sediment loads varied from 350 to $600 \mathrm{~kg} \mathrm{ha}^{-1}$, and annual return flow loads varied from 160 to $440 \mathrm{~kg} \mathrm{ha}^{-1}$. The average annual net sediment gain in the watershed was $165 \mathrm{~kg} \mathrm{ha}^{-1}$ (table 2). Diverting irrigation water into this watershed removed, on average, $13,000 \mathrm{Mg}$ of sediment from

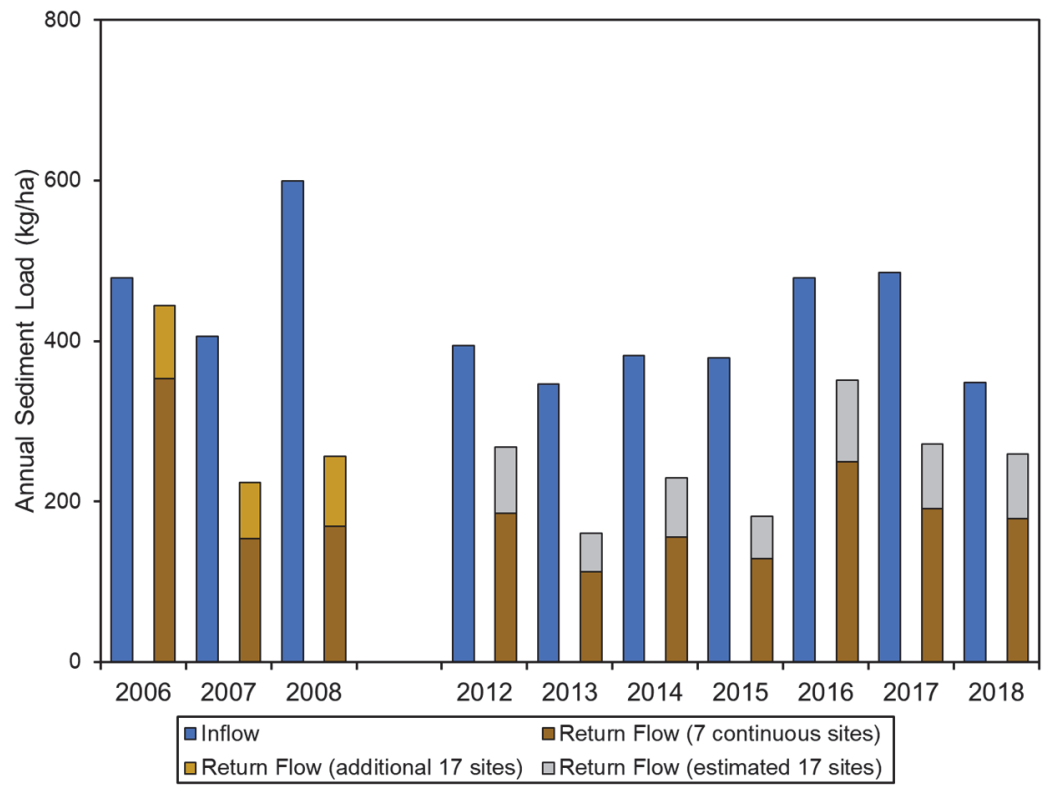

Figure 4. Annual sediment loads in watershed inflow and irrigation return flow; 24 sites were measured during 2006 to 2008 , but only seven of these sites were continued during 2012 to 2018. 
Table 2. Mean total annual flow and parameter loads for watershed inflow and return flow (standard deviations in parentheses). Annual return flow loads are the sum of all sites measured during 2006 to 2008 and the sum of estimated annual totals based on the relative contribution of the seven sites measured from 2012 to 2018.

\begin{tabular}{cccc}
\hline Parameter & Inflow & Return Flow & Difference \\
\hline Flow amount $(\mathrm{mm})$ & $1275(146)$ & $467(82)^{*}$ & 808 \\
Sediment $\left(\mathrm{kg} \mathrm{ha}^{-1}\right)$ & $430(80)$ & $265(82)^{*}$ & 165 \\
Total P $\left(\mathrm{kg} \mathrm{ha}^{-1}\right)$ & $0.9(0.3)$ & $0.5(0.2)^{*}$ & 0.4 \\
Dissolved P $\left(\mathrm{kg} \mathrm{ha}^{-1}\right)$ & $0.2(0.2)$ & $0.2(0.1) \mathrm{ns}$ & $<0.1$ \\
Soluble salts $\left(\mathrm{kg} \mathrm{ha}^{-1}\right)$ & $3400(384)$ & $2040(310)^{*}$ & 1360 \\
Nitrate-N $\left(\mathrm{kg} \mathrm{ha}^{-1}\right)$ & $0.8(0.7)$ & $11(1.6)^{*}$ & -10 \\
\hline Aa] & Asterisks $(*)$ indicate that inflow and return flow concentrations are \\
significantly different $(\mathrm{p}<0.05) ;$ "ns" is not significant.
\end{tabular}

Table 3. Mean annual flow-weighted parameter concentrations for two inflow and the seven return flow sites that were measured from 2006 to 2008 and 2012 to 2018 (standard deviations in parentheses).

\begin{tabular}{ccccc}
\hline & $\begin{array}{c}\text { Inflow } \\
\left(\mathrm{mg} \mathrm{L}^{-1}\right)\end{array}$ & Trend $^{[\mathrm{a}]}$ & $\begin{array}{c}\text { Return Flow } \\
\left(\mathrm{mg} \mathrm{L}^{-1}\right)\end{array}$ & Trend $^{[\mathrm{b}]}$ \\
\hline Parameter & $34(6.3)$ & Decreasing & $52(15)^{*}$ & - \\
Sediment & $0.07(0.03)$ & Decreasing & $0.11(0.03)^{*}$ & Decreasing \\
Total P & $0.02(0.01)$ & Decreasing & $0.04(0.02)^{*}$ & Decreasing \\
Dissolved P & $0.02(31)^{*}$ & Decreasing \\
Soluble salts & $267(21)$ & - & $454(30)$ & - \\
Nitrate-N & $0.06(0.05)$ & - & $2.42(0.20)^{*}$ & - \\
\hline
\end{tabular}

[a] Significant trend determined by Mann-Kendall trend test $(\mathrm{p}<0.05)$. Blank (-) indicates no trend.

[b] Asterisks $(*)$ indicate that inflow and return flow concentrations are significantly different $(\mathrm{p}<0.05)$.

the Snake River each year from 2006 to 2018 . While this is a considerable improvement from 1971 when $38,000 \mathrm{Mg}$ were lost from the watershed (Carter et al., 1974), average annual flow-weighted sediment concentration in return flow was still about $50 \%$ greater than the inflow concentration (table 3). Efforts need to continue to reduce sediment loss from fields, especially furrow irrigated fields, and improve sediment removal in water quality ponds. Improved irrigation management could also reduce the amount of water flowing back to the Snake River, which could further reduce sediment losses. A recent study showed that return flow from this watershed had a slight increasing trend during the 2006 to 2016 time period even though farmers were consistently converting from furrow irrigation to sprinkler irrigation (Bjorneberg et al., 2020).

\section{PhOSPHORUS}

Berg and Carter (1980) documented that dissolved and total phosphorus losses from the 49 furrow irrigated fields in the TFCC watershed ranged from $<0.1$ to $2.3 \mathrm{~kg} \mathrm{ha}^{-1}$ and from 0.3 to $141 \mathrm{~kg} \mathrm{ha}^{-1}$, respectively, in 1978 and 1979 . Even though P losses from fields can be large, the watershed received more dissolved and total $\mathrm{P}$ with irrigation water than returned to the river in 1971. Annual dissolved $\mathrm{P}$ input was $0.35 \mathrm{~kg} \mathrm{ha}^{-1}$ and output was $0.31 \mathrm{~kg} \mathrm{ha}^{-1}$ for a net gain of 0.4 $\mathrm{kg} \mathrm{ha}^{-1}$ of dissolved P (Carter et al., 1974). Annual total P input was $2.3 \mathrm{~kg} \mathrm{ha}^{-1}$ and output was $1.2 \mathrm{~kg} \mathrm{ha}^{-1}$ for a net gain of $1.1 \mathrm{~kg} \mathrm{ha}^{-1}$ of total P. Phosphorus was retained in the watershed because $70 \%$ of the irrigation water was retained within the watershed. The reason that there was net deposition of $\mathrm{P}$ and net loss of sediment in 1971 was that sediment concentration in return flow was 5.5 times greater than the inflow concentrations, while $\mathrm{P}$ concentrations were 3.5 and 1.8 times greater for dissolved and total $\mathrm{P}$, respectively (Carter et al., 1974).

Recent data show the continuing trend of more total $\mathrm{P}$ entering the watershed than leaving, with the exception of 2017 (fig. 5). High flows in the Snake River prior to the 2017 irrigation season may have impacted $P$ concentrations in the river, or there may have been some change in upstream $P$ sources because the inflow P load was also lower in 2018 than in previous years (fig. 5). Furthermore, flooding increased flow and total P load in return flow streams in February and March 2017. Average annual net deposition of total P was only $0.4 \mathrm{~kg} \mathrm{ha}^{-1}$ (table 2) or about $30 \mathrm{Mg}$ year $^{-1}$ for the entire watershed. There was a significant decreasing trend for both inflow and return flow total P concentrations (table 3), indicating that water quality improved in the Snake River and TFCC return flow.

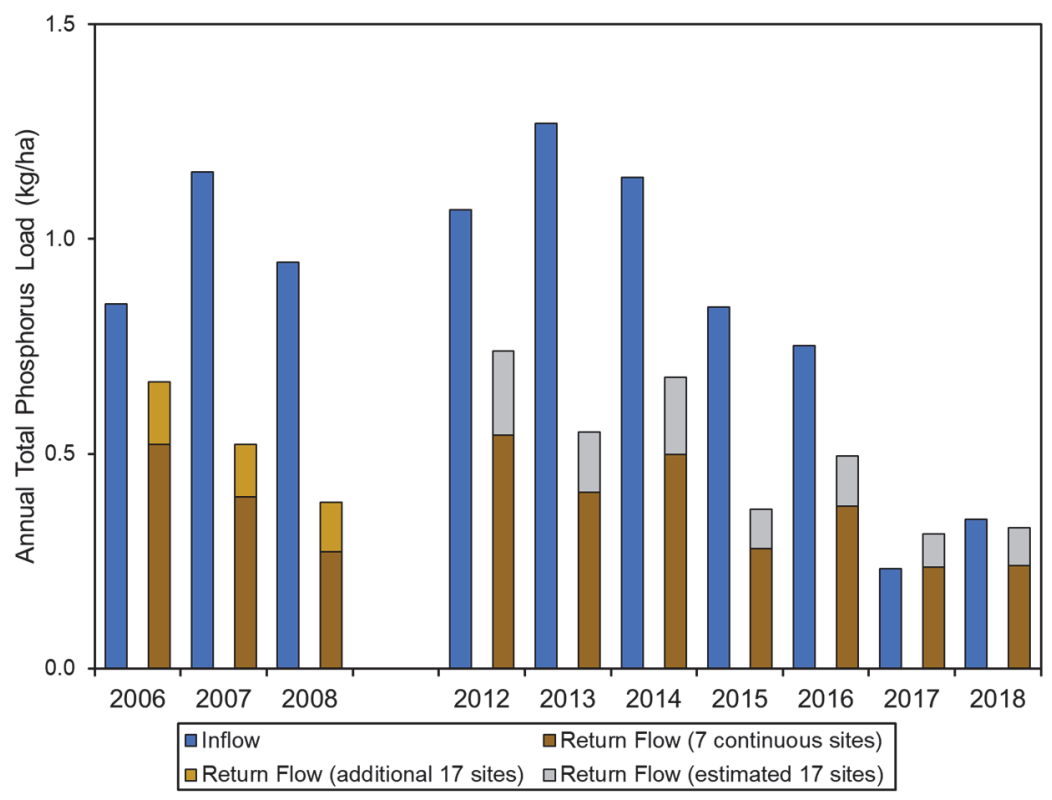

Figure 5. Annual total phosphorus loads in watershed inflow and irrigation return flow; 24 sites were measured during 2006 to 2008 , but only seven of these sites were continued during 2012 to 2018. 
Dissolved P concentrations also had significant decreasing trends for both inflow and return flow (table 3). Inflow dissolved $\mathrm{P}$ loads were greater than return flow loads for 2006 to 2008 but were less than return flow loads for 2012 to 2018 (fig. 6). As dissolved P concentrations decreased, a greater number of samples had concentrations $<0.01 \mathrm{mg} \mathrm{L}^{-1}$, which was the minimum detection limit used for this analysis. Samples with concentrations $<0.01 \mathrm{mg} \mathrm{L}^{-1}$ were assigned a concentration of 0 . Only $3 \%$ of the samples from the main canal were $<0.01 \mathrm{mg} \mathrm{L}^{-1}$ for 2006 to 2008 , but $63 \%$ were $<0.01 \mathrm{mg} \mathrm{L}^{-1}$ for 2012 to 2018 . This is another indication that water quality in the Snake River is improving.

\section{Soluble SALTS}

Carter et al. (1971) measured $5,700 \mathrm{~kg} \mathrm{ha}^{-1}$ year $^{-1}$ of soluble salts in canal water flowing into the watershed and estimated that $8,160 \mathrm{~kg} \mathrm{ha}^{-1}$ year $^{-1}$ returned to the river for an annual net loss of $2,400 \mathrm{~kg} \mathrm{ha}^{-1}$ of soluble salts from the TFCC watershed. Their estimate was based on the assumption that all water that was not accounted for in the water balance (i.e., closure error) was deep percolation that eventually returned to the Snake River by subsurface flow. They assumed that this water had the same salt concentration as they measured from the drain tunnels/tiles. Their assumption was appropriate for their objective of determining if salts were accumulating in the root zone. This assumption also may have been more appropriate when $90 \%$ of the cropland was furrow irrigated and deep percolation was likely widespread, compared to current conditions when $60 \%$ of the cropland is sprinkler irrigated. Data from 2006 to 2018 showed that inflow contributed $3,400 \mathrm{~kg} \mathrm{ha}^{-1}$ year $^{-1}$ of soluble salts while return flow only removed $2,040 \mathrm{~kg} \mathrm{ha}^{-1}$ year $^{-1}$ for a net deposition of $1,360 \mathrm{~kg} \mathrm{ha}^{-1}$ year $^{-1}$ (table 2).

The concentration of soluble salts was greater in return flow than inflow due to the higher soluble salt concentrations in flow from the drain tunnels/tiles (table 4). Return flow streams without drain tunnels/tiles have similar soluble salt concentrations as the main canal, while streams with tunnels/tiles have significantly greater soluble salt concentrations (table 4). There was a significant decreasing trend in soluble salt concentrations in return flow from 2006 to 2018 (table 3), indicating that the drain tunnels/tiles are contributing a smaller percentage of the total return flow and likely removing fewer salts from the watershed, assuming that tunnel/tile salt concentrations were not changing. Salt accumulation in the watershed has not been a major concern because

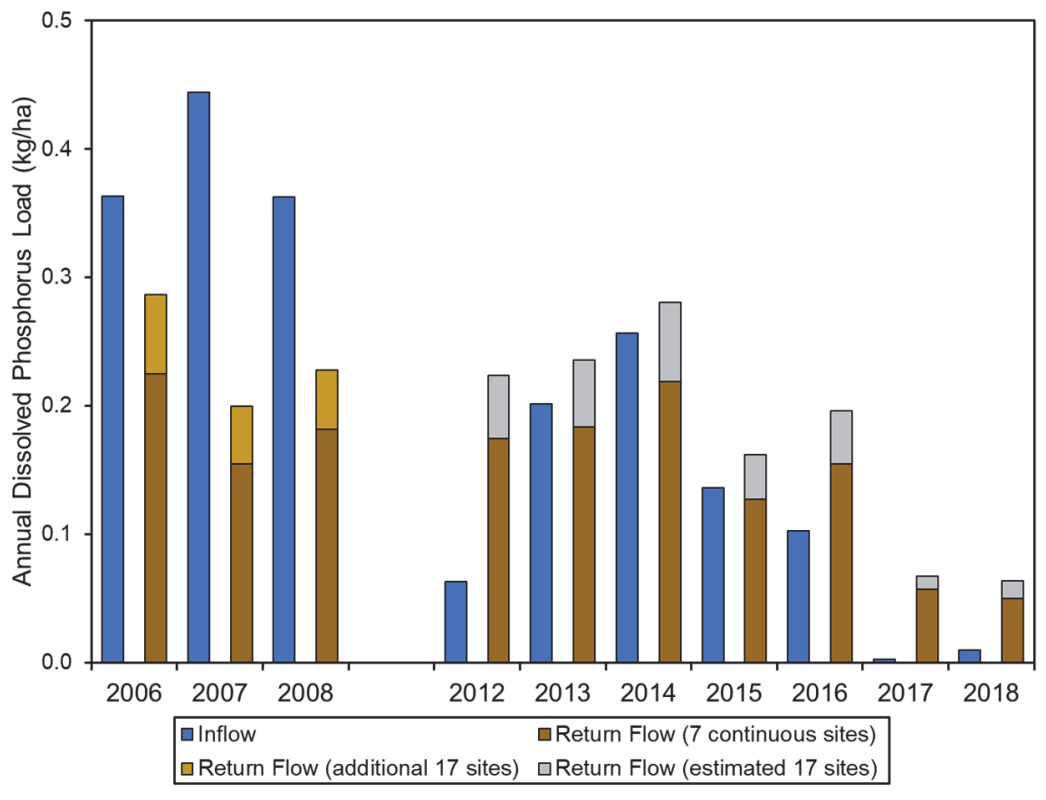

Figure 6. Annual dissolved phosphorus loads in watershed inflow and irrigation return flow; 24 sites were measured during 2006 to 2008 , but only seven of these sites were continued during 2012 to 2018.

Table 4. Mean annual flow-weighted soluble salt and nitrate-N concentrations in winter (November to March) and summer at each site that was measured from 2006 to 2008 and 2012 to 2018 (standard deviations in parentheses). Sites without drain tunnels/tiles did not flow during winter.

\begin{tabular}{|c|c|c|c|c|c|c|c|c|c|}
\hline \multirow[b]{2}{*}{ Site } & \multirow[b]{2}{*}{$\begin{array}{c}\text { Drain } \\
\text { Tunnels/Tiles }\end{array}$} & \multicolumn{4}{|c|}{ Soluble Salts } & \multicolumn{4}{|c|}{ Nitrate-N } \\
\hline & & $\begin{array}{l}\text { Winter } \\
\left(\mathrm{mg} \mathrm{L}^{-1}\right)\end{array}$ & Trend $^{[\mathrm{a}]}$ & $\begin{array}{c}\text { Summer }^{[\mathrm{b}]} \\
\left(\mathrm{mg} \mathrm{L}^{-1}\right)\end{array}$ & Trend $^{[\mathrm{a}]}$ & $\begin{array}{l}\text { Winter } \\
\left(\mathrm{mg} \mathrm{L}^{-1}\right)\end{array}$ & Trend $^{[\mathrm{a}]}$ & $\begin{array}{l}\text { Summer }^{[\mathrm{b}]} \\
\left(\mathrm{mg} \mathrm{L}^{-1}\right)\end{array}$ & Trend $^{[\mathrm{a}]}$ \\
\hline A10 & No & No flow & - & $270(16)$ & - & No flow & - & $0.05(0.04)$ & - \\
\hline $\mathrm{CD}$ & Yes & $576(35)$ & Decrease & $399(41)^{*}$ & Decrease & $4.77(0.42)$ & - & $1.56(0.43)^{*}$ & Decrease \\
\hline $\mathrm{DC}$ & Yes & $581(23)$ & Decrease & $402(36) *$ & Decrease & $5.51(0.67)$ & Increase & $1.77(0.22)^{*}$ & Decrease \\
\hline $\mathrm{IC}$ & Yes & $546(13)$ & Decrease & $448(24) *$ & Decrease & $5.15(0.37)$ & Increase & $2.26(0.22)^{*}$ & Decrease \\
\hline $\mathrm{MC}$ & Yes & $588(11)$ & - & $516(30)^{*}$ & Decrease & $4.56(0.37)$ & Increase & $2.49(0.16)^{*}$ & Decrease \\
\hline $\mathrm{NC}$ & No & No flow & - & $274(77)$ & - & No flow & - & $0.06(0.06)$ & - \\
\hline RCP & Yes & 492 (44) & - & $425(38)^{*}$ & - & $3.05(0.28)$ & - & $1.89(0.21)^{*}$ & - \\
\hline Canal & - & No flow & - & $270(21)$ & - & No flow & - & $0.06(0.05)$ & - \\
\hline Rock Creek & - & $96(18)$ & - & $67(7)^{*}$ & - & $0.06(0.05)$ & - & $0.07(0.05)^{*}$ & - \\
\hline
\end{tabular}

[a] Significant trend determined by Mann-Kendall trend test $(\mathrm{p}<0.05)$. Blank indicates no trend.

[b] Asterisks $(*)$ indicate that concentration is significantly different from Canal $(\mathrm{p}<0.05)$. 
the salt and sodium concentrations in irrigation water are not considered high. The average soluble salt concentration was $450 \mathrm{mg} \mathrm{L}^{-1}$ (table 3 ), and the average sodium adsorption ratio (SAR) was only 0.7 (data not shown). Irrigation water with 160 to $480 \mathrm{mg} \mathrm{L}^{-1}$ salt concentration is a considered medium salinity hazard, and SAR $<6$ is a low sodic hazard (Cuenca, 1989). However, this salt balance only includes additions from irrigation water and removal with irrigation return flow. It does not include additions by fertilizers and manure or removal with harvested crops.

\section{NitRogen}

Average annual nitrate-N inflow concentrations for 2006 to 2018 were $0.06 \mathrm{mg} \mathrm{L}^{-1}$ (table 3 ) compared to $0.12 \mathrm{mg} \mathrm{L}^{-1}$ measured by Carter et al. (1971), indicating that nitrate-N concentrations in the Snake River have decreased. Carter et al. (1971) measured $2.3 \mathrm{~kg} \mathrm{ha}^{-1}$ year $^{-1}$ of nitrate-N in canal water flowing into the watershed. Using the same deep percolation assumption used for soluble salts, they estimated that $35.7 \mathrm{~kg} \mathrm{ha}^{-1}$ year $^{-1}$ of nitrate-N returned to the Snake River for a net loss of $33.4 \mathrm{~kg} \mathrm{ha}^{-1}$ year $^{-1}$. In 2006 to 2018 , only $0.8 \mathrm{~kg} \mathrm{ha}^{-1}$ year $^{-1}$ of nitrate- $\mathrm{N}$ flowed into the watershed because less irrigation water was diverted compared to 19681970 and nitrate-N concentrations in the Snake River were lower. Return flow transported $11 \mathrm{~kg} \mathrm{ha}^{-1}$ year $^{-1}$ to the Snake River for an annual net loss of $10 \mathrm{~kg} \mathrm{ha}^{-1}$ (table 2). Overall, less nitrate- $\mathrm{N}$ is entering the watershed with irrigation water and less is leaving the watershed with return flow compared to $1968-1970$. However, $800 \mathrm{Mg}$ of nitrate-N was lost from the watershed each year.

The current data do not indicate an increasing or decreasing trend for annual inflow or return flow nitrate-N concentrations (table 3). Overall, annual return flow concentrations were significantly greater than inflow concentrations due to nitrate- $\mathrm{N}$ contribution from the drain tunnels/tiles, similar to soluble salts. Return flow streams without tunnels/tiles did not flow during the winter (November to March), and nitrate- $\mathrm{N}$ concentrations in these streams were low and not significantly different from the main canal concentrations (table 4). Sites with tunnels/tiles continued to flow after irrigation diversion stopped in late October and had nitrate-N concentrations that were 25 to 40 times greater than the canal water. Almost all of the nitrate- $\mathrm{N}$ in the return flow originated from tunnel/tile flow.

Summer nitrate- $\mathrm{N}$ concentrations at four return flow sites had decreasing trends. Return flow in the summer is a combination of unused irrigation water, furrow irrigation runoff, and drain tunnel/tile flow. Concentrations in the summer could be decreasing because flow from drain tunnels/tiles was decreasing as more land was converted from furrow irrigation to sprinkler irrigation, resulting in tunnels/tiles contributing a smaller proportion of the total return flow in the summer. In the winter, all of the return flow was from tunnels/tiles. Three of the return flow streams had increasing trends for winter nitrate- $\mathrm{N}$ concentrations (table 4), indicating that nitrate- $\mathrm{N}$ concentrations in the shallow groundwater are increasing. Lentz et al. (2018) measured nitrate-N concentrations in ten drain tunnels in this watershed that were 1.4 times greater in the early 2000s than the late 1960s (increased from 3.06 to $5.06 \mathrm{mg} \mathrm{L}^{-1}$ ). These results indicate that irrigation and nutrient management should be a priority to reduce potential nitrogen leaching.

\section{HYDROELECTRIC GENERATION}

In addition to improving irrigation return flow water quality, TFCC has three hydroelectric generation facilities on its canals. These hydroelectric plants generate electricity as water flows through the canals during the irrigation season. Seven additional hydroelectric plants are located on irrigation return flow streams. These facilities can generate electricity all year as water from drain tunnels/tiles flows back to the Snake River. Power generation data were publicly available for six of these plants. Average annual power generation from 2001 to 2018 was 64,800 MWh for these six plants (EIA, 2020). From May through September, 34,000 MWh were generated, which is enough power to pump approximately $213,000,000 \mathrm{~m}^{3}$ of water assuming discharge pressure of $345 \mathrm{kPa}$ and $60 \%$ efficiency. The hydroelectric power generated by these six plants was enough to apply approximately $260 \mathrm{~mm}$ to all cropland in the TFCC project. Hydroelectric power generation is another component of improved sustainability in the Twin Falls irrigation project.

\section{CONCLUSIONS}

The Twin Falls Canal Company is considered one of the most successful Carey Act irrigation projects. Through the use of conservation practices, including conversion from furrow to sprinkler irrigation, edge-of-field sediment basins, and large-scale water quality ponds on irrigation return flow streams, water quality has improved over time. While sediment and phosphorus concentrations in irrigation return flow have decreased, they were still greater than the irrigation water that was diverted into the watershed, and nitrate-N concentrations were trending upward. Conservation efforts need to continue to reduce sediment loss and nutrient losses to reduce the project's influence on water quality in the Snake River.

\section{ACKNOWLEDGEMENTS}

This research was partially supported with funding from the USDA-NRCS Conservation Effects Assessment Project and cooperation from the Twin Falls Canal Company and Idaho Department of Water Resources.

\section{REFERENCES}

Berg, R. D., \& Carter, D. L. (1980). Furrow erosion and sediment losses on irrigated cropland. J. Soil Water Cons., 35(6), 267-270.

Bjorneberg, D. L., King, B. A., \& Koehn, A. C. (2020). Watershed water balance changes as furrow irrigation is converted to sprinkler irrigation in an arid region. J. Soil Water Cons., 75(3), 254-262. https://doi.org/10.2489/jswc.75.3.254

Bjorneberg, D. L., Leytem, A. B., Ippolito, J. A., \& Koehn, A. C. (2015). Phosphorus losses from an irrigated watershed in the northwestern United States: Case study of the Upper Snake Rock watershed. J. Environ. Qual., 44(2), 552-559. https://doi.org/10.2134/jeq2014.04.0166

Bjorneberg, D. L., Prestwich, C. J., \& Evans, R. G. (2007). Evaluating the surface irrigation soil loss (SISL) model. Appl. 
Eng. Agric., 23(4), 485-491. https://doi.org/10.13031/2013.23490

Bjorneberg, D. L., Westermann, D. T., Nelson, N. O., \& Kendrick, J. H. (2008). Conservation practice effectiveness in the irrigated Upper Snake River/Rock Creek watershed. J. Soil Water Cons., 63(6), 487-495. https://doi.org/10.2489/jswc.63.6.487

Brown, M. J., Carter, D. L., \& Bondurant, J. A. (1974). Sediment in irrigation and drainage waters and sediment inputs and outputs for two large tracts in southern Idaho. J. Environ. Qual., 3(4), 347-351. https://doi.org/10.2134/jeq1974.00472425000300040010x

Carter, D. L., Bondurant, J. A., \& Robbins, C. W. (1971). Watersoluble $\mathrm{NO}_{3}$-nitrogen, $\mathrm{PO}_{4}$-phosphorus, and total salt balances on a large irrigation tract. SSSA J., 35(2), 331-335. https://doi.org/10.2136/sssaj1971.03615995003500020042x

Carter, D. L., Brown, M. J., Robbins, C. W., \& Bondurant, J. A. (1974). Phosphorus associated with sediments in irrigation and drainage waters for two large tracts in southern Idaho. $J$. Environ. Qual., 3(3), 287-291. https://doi.org/10.2134/jeq1974.00472425000300030022x

Carey Act. (1912). Private irrigation projects: Carey Act. Hearing before the Committee on Irrigation and Reclamation of Arid Lands, U.S. Senate, Sixty-Second Congress. January 15, 1912. Washington, DC: Government Printing Office.

Census. (1922). Fourteenth census of the United States taken in the year 1920: Volume VII. Irrigation and drainage. Washington, DC: Bureau of the Census. Retrieved from http://agcensus.mannlib.cornell.edu/AgCensus/censusParts.do?y ear $=1920$

Cuenca, R. H. (1989). Principles of soil chemistry. In Irrigation system design: An engineering approach (pp. 86-114). Englewood Cliffs, NJ: Prentice-Hall.

EIA. (2020). U.S. energy mapping system. Washington, DC: U.S. Energy Information Administration. Retrieved from https://www.eia.gov/state/maps.php
Ganoe, J. T. (1937). The Desert Land Act in operation, 1877-1891. Agric. History, 11(2), 142-157. Retrieved from https://www.jstor.org/stable/3739672

Landstrom, K. S. (1954). Reclamation under the Desert Land Act. American J. Agric. Econ., 36(3), 500-508. https://doi.org/10.2307/1233016

Lentz, R. D., Carter, D. L., \& Haye, S. V. (2018). Changes in groundwater quality and agriculture in forty years on the Twin Falls irrigation tract in southern Idaho. J. Soil Water Cons., 73(2), 107-119. https://doi.org/10.2489/jswc.73.2.107

Lentz, R. D., Sojka, R. E., Carter, D. L., \& Shainberg, I. (1992). Preventing irigation furrow erosion with small applications of polymers. SSSA J., 56(6), 1926-1932. https://doi.org/10.2136/sssaj1992.03615995005600060046x

Lovin, H. T. (1987). Carey Act in Idaho, 1895-1925: An experiment in free enterprise reclamation. Pacific Northwest Qtly., 78(4), 122-133. Retrieved from www.jstor.org/stable/40490218

Moon, J. H., \& Tremayne, R. M. (2005). A history of the Twin Falls Canal Company. Twin Falls, ID: Blip Printers.

SAS. (2014). SAS online documentation (ver. 9.4). Cary, NC: SAS Institute, Inc.

TFCC. (2020). Twin Falls Canal Company website. Twin Falls, ID: Twin Falls Canal Company. Retrieved from http://twinfallscanal.com/

USDA. (2020a). Census of Agriculture Historical Archive. Washington, DC: USDA National Agricultural Statistics Service. Retrieved from http://agcensus.mannlib.cornell.edu/AgCensus/homepage.do

USDA. (2020b). Census of Agriculture. Washington, DC: USDA National Agricultural Statistics Service. Retrieved from https://www.nass.usda.gov/AgCensus/index.php

USEPA. (1983). Methods for chemical analysis of water and wastes. EPA-600/4-79-020. Rev. March 1983, Method 351.2. Washington, DC: U.S. Environmental Protection Agency. 